\title{
Understanding Exercise Physiology through the Eswatini Traditional and Cultural Dances
}

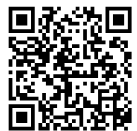

\author{
Adiele Dube* \\ Department of Health Education, Southern Africa Nazarene University (SANU), Eswatini
}

Submission: April 10, 2020; Published: April 23, 2020

*Corresponding author: Adiele Dube, Department of Health Education, Southern Africa Nazarene University (SANU), Eswatini

\begin{abstract}
Exercise science incorporates various subjects which include Biomechanics, Exercise Physiology, Kinesiology, and Psychology among others. These are extensively applied and are useful in the field of dance. In southern African context, the Eswatini's traditional and cultural dances are not only regarded as a form art with technical and expressive aspects but also sports form due to their high physiological capacities. These dances are diverse, intermittent, with moderate to high intensity. They are complex in that, no clear distinction between training, performance intensities and durations can be drawn. Considering dance as a sport and an art it is of paramount importance to understand the physiological strain on the dancers. Like any sport, a sound dance science is a significant requirement to achieve optimal performance and sustain it throughout the stages of the dancing career for an athlete. Despite the fact that we are now in the mid-21st century, most of southern Africa traditional dances are not documented compared to traditional games, dance science has been fast growing in the developed nations. Understanding dance science in academic and sport spheres is of paramount importance. Dance science should to be taught to dancers with focus of how they can improve their trained state and achieve optimal performance through understanding the cycles of periodization training and nutrition to allow them to prepare for events more efficiently. Therefore, the current paper discusses the physiological aspects such as physical fitness, energy systems, energy intake and expenditure, conditioning training and injury prevention, and rest in Eswatini traditional dances.
\end{abstract}

Keywords: Physical fitness, Dance science, EmaSwati dances, V02max

Abbreviations: CBE: Curriculum Based Education; HPE: Health and Physical Education; CNS: Central Nervous System; PC: PhosphoCreatine; ADP: Adenosine Diphosphate; P: Phosphate; Pi: Single Phosphate

\section{Introduction}

The Kingdom of Eswatini (formerly Swaziland) is a small land locked country located in the Southern sub-Sahara region with a population approximately 1.3 million. It is a country of the Swazi people, who are predominantly referred to as EmaSwati. EmaSwati are proud, cheerful yet peaceful and friendly people who carefully guard their customs and values and regularly hold colorful traditional ceremonies [1]. Music and dance during ceremonies are distinctive features embedded in the Swazi culture as they help to bring unity to the Swazi nation [2]. The Swazi culture stalwarts on the importance and significance of the song and dance. It can be noted that the main tradition amongst EmaSwati is music and dance. Dance development can be multi-dimensional among individuals bringing about positive improvements when individuals dance as a sportive activity, physical or cultural fulfillment.

\section{Background}

The Kingdom of Eswatini is working towards, striving and making efforts to achieve the United Nations' Sustainable
Development Goals (SDGs). Inclusive under discussion are Goals: 3; Good Health and Well-being; 16; Peace, Justice and Strong Institutions and 17; Partnership for the Goals [3]. These SDGs are embedded through the Eswatini customs, culture and tradition specifically through their traditional and cultural activities which are spread throughout the year. The Eswatini culture is colored and flourished by a number of dance types which deduce different meanings. To date, different culture groups are assembled to compete during the finals for Ingwenyama cup (Ingwenyama cup - His Majesty King Mwasti III annual football cup officially sponsored by Sincephetelo Motor Vehicle Accident Fund SMVAF). These groups are lined up in 4 main categories which are: Timbongi - praising His Majesty, the King; Sibhaca/Ingadla - skills display showing love for EmaSwati culture; and Lutsango - appraising and appreciation for Her Majesty, the Queen mother [2] . Not only that, the cultural dance groups make EmaSwati happy and joyful and they revive culture among the country's four regions. Most of Eswatini dances are accompanied by songs, though a few incorporate beating the drum and clapping. Of note 
is that the dances which encompass the drum are performed within a short duration as compared to the dances and singing which can lapse for more than 3 hours.

Dance professionals devote a couple of years to training to perfect the skills; often from a young age to attain one of the few positions available in professional dance companies. A position is obtained after being subjected to fierce competition from other talented dancers as well as intense scrutiny from teachers, choreographers, and artistic directors, so they must possess innate talent, a high level of skill and physical ability [4]. Within the Eswatini culture, training for dancers is done from childhood when children are in the homesteads with parents or/and family elders. This is done mostly in the early hours of the night after dinner, before going to sleep where boys are guided by father, brothers or any other family elderly men while girls are guided by their mothers, elderly sisters or any other elder member of the female family side. The teaching is done separately, hence not only dances are taught but also gender roles and responsibilities, inline with boyhood and girlhood. Training of songs, dances and Swazi moral values is done throughout the year at different levels: family level, Umphakatsi residence (head of the community) till the national level. It is important to note that fine tuning of songs and dances are done at each level before the dancers are ordained to the next level. Despite that, the songs for these levels may be totally different, dances are the same except for the ones at national level where the ceremony determines how those dance should be performed. To note is that, there are Swazi dances which are done accompanying work or movement from one place to another; for example when the maidens are going to collect the reed [5], hence, are known as dances for 'Kuhlehla' and some are done with little movement covering a small area; for example when the maidens sing in front of the Royal residence during the Umhlanga ceremony, hence are known as 'Kuhlehla' . There are two main kinds of dances done by men and women respectively at most traditional, cultural and gatherings throughout the year [6]. Eswatini's blueprint traditional and cultural events are: Incwala (the most sacred Festival with undocumented period but celebrations include the First Fruits with main functions between December - January); Maganu (the Marula Festival; February - May), Butimba (the Royal Hunt; End of August), and Umhlanga (the Reed Dance; End of August -early September) [2,5-8]. Literature reveals that physical inactivity's prevalence of the Kingdom of eSwatini's men and women are 72.7 $(67.9,77.6)$ and $60.6(56.7,64.5)$ respectively at 95\% CI [9] are not spared among the World Health Organization (WHO) member states facing physical inactivity predicament. A close monitoring of highrisk populations such as children, adolescents, tertiary education and young age working population is essential to track the effectiveness of the policy and future guide plan.

Table 1: The Eswatini Traditional and Cultural dances.

\begin{tabular}{|c|c|c|c|c|c|c|}
\hline Dance Type & Age group & Duration & Performer & Description & Ceremony & Function \\
\hline \multirow[t]{2}{*}{$\begin{array}{c}\text { Ummiso - is } \\
\text { performed in } 2 \\
\text { main categories } \\
\text { ie: dance with } \\
\text { movement \& with } \\
\text { minimal move- } \\
\text { ment }\end{array}$} & $\begin{array}{l}\text { Young and old } \\
\text { women }\end{array}$ & $3+$ hours & $\begin{array}{c}\text { - performed by married } \\
\text { women category known as } \\
\text { 'Lutsango' }\end{array}$ & $\begin{array}{l}\text { - by woman } \\
\text { wearing a black } \\
\text { skirt called Sid- } \\
\text { vwaba made out } \\
\text { of a cow skin and } \\
\text { other tradition- } \\
\text { al attire and also } \\
\text { by young ladies. }\end{array}$ & $\begin{array}{l}\text { Maganu (Maru- } \\
\text { la) Festival }\end{array}$ & $\begin{array}{c}\text {-women pay homage to } \\
\text { their Majesties - King and } \\
\text { Queen of Eswatini. }\end{array}$ \\
\hline & $\begin{array}{l}\text { Young older } \\
\text { girls not yet } \\
\text { married }\end{array}$ & & $\begin{array}{l}\text { - performed also by girls } \\
\text { locally named 'Imbali'(maid- } \\
\text { ens) [5] }\end{array}$ & $\begin{array}{l}\text {-rhythmic dance } \\
\text { for displaying } \\
\text { pride in culture. }\end{array}$ & $\begin{array}{c}\text { Umhlanga } \\
\text { (Reed dance) }\end{array}$ & $\begin{array}{l}\text {-girls pay homage to } \\
\text { the King and Queen of } \\
\text { Eswatini. }\end{array}$ \\
\hline $\begin{array}{l}\text { Sibhaca - known } \\
\text { for various dance } \\
\text { forms }\end{array}$ & $\begin{array}{l}\text { Mainly boys } \\
\text { and young men }\end{array}$ & $\leq 30 \mathrm{mins}$ & $\begin{array}{l}\text {-performed by men and } \\
\text { boys, though a few well } \\
\text { trained older girls can } \\
\text { perform. However, girls in } \\
\text { the background mainly sing, } \\
\text { clap hands or beat drum }\end{array}$ & $\begin{array}{l}\text { High strenuous; } \\
\text { team of dancers } \\
\text { step forward in } \\
\text { turn to per- } \\
\text { form a barefoot } \\
\text { high-kicking and } \\
\text { stomping, while } \\
\text { their compan- } \\
\text { ions behind beat } \\
\text { drums, chant and } \\
\text { sing. }\end{array}$ & $\begin{array}{l}\text { Any traditional } \\
\text { ceremony as } \\
\text { entertainment } \\
\text { eg wedding, } \\
\text { and any com- } \\
\text { munity event }\end{array}$ & $\begin{array}{c}\text {-in the ancient days when } \\
\text { preparing for war }\end{array}$ \\
\hline Ingadla & $\begin{array}{l}\text { Older girls and } \\
\text { young single } \\
\text { mothers }\end{array}$ & $\leq 30 \mathrm{mins}$ & $\begin{array}{l}\text {-performed by older girls or } \\
\text { single mothers who have not } \\
\text { been formally married. }\end{array}$ & $\begin{array}{l}\text {-high kicking } \\
\text { dance but is } \\
\text { different in exe- } \\
\text { cution between } \\
\text { young men and } \\
\text { older girls }\end{array}$ & $\begin{array}{l}\text { Any traditional } \\
\text { ceremony as } \\
\text { entertainment. } \\
\text { eg wedding } \\
\text { and any com- } \\
\text { munity event }\end{array}$ & $\begin{array}{c}\text {-girls pay homage to the } \\
\text { King and the Queen Moth- } \\
\text { er of Eswatini. }\end{array}$ \\
\hline
\end{tabular}




\begin{tabular}{|c|c|c|c|c|c|c|}
\hline Sizingili & $\begin{array}{l}\text { Old boys and } \\
\text { young men }\end{array}$ & \pm 1 hour & $\begin{array}{l}\text {-performed by boys and } \\
\text { young men -done after a } \\
\text { victory of a war }\end{array}$ & $\begin{array}{c}\text {-ancient energetic } \\
\text { fast moving dance } \\
\text { with high kicking } \\
\text { action, sometimes } \\
\text { resembling animal } \\
\text { movements } \\
\text { performed by } \\
\text { the active men } \\
\text { wearing Emajobo } \\
\text { and Angolian goat } \\
\text { skin. }\end{array}$ & $\begin{array}{l}\text {-Umtsimba } \\
\text { (Swazi Wed- } \\
\text { ding ceremo- } \\
\text { ny) }\end{array}$ & $\begin{array}{l}\text { Pride of the Swazi tradi- } \\
\text { tional wedding }\end{array}$ \\
\hline Kugiya & $\begin{array}{l}\text { Girls, women, } \\
\text { boys and men }\end{array}$ & \pm 1 hour & $\begin{array}{c}\text {-performed by married } \\
\text { women whose attire clearly } \\
\text { distinguishes them from the } \\
\text { younger ladies }\end{array}$ & $\begin{array}{l}\text {-the dance do not } \\
\text { allow high step } \\
\text { and is character- } \\
\text { ised by swinging } \\
\text { movements with } \\
\text { foot sliding action. }\end{array}$ & $\begin{array}{l}\text {-Umtsimba } \\
\text { (Swazi Wed- } \\
\text { ding ceremo- } \\
\text { ny) }\end{array}$ & $\begin{array}{l}\text { Pride of the Swazi tradi- } \\
\text { tional wedding }\end{array}$ \\
\hline Kutsamba & women & $3+$ hours & $\begin{array}{l}\text {-performed mainly by mar- } \\
\text { ried women (Lutsango) }\end{array}$ & & $\begin{array}{l}\text { Maganu (Maru- } \\
\text { la Festival) }\end{array}$ & Pride of Swazi culture \\
\hline Umgubho & males & \pm 1 hour & -performed by males & $\begin{array}{l}\text { Deep cultural } \\
\text { songs when men } \\
\text { are holding sticks } \\
\text { and shields }\end{array}$ & $\begin{array}{l}\text { Umhlanga } \\
\text { (Reed dance) }\end{array}$ & Pride of Swazi culture \\
\hline Kukosha & males & $30+\operatorname{mins}$ & -performed by boys and men & $\begin{array}{l}\text {-is a special dance } \\
\text { for boys and men } \\
\text { that displays their } \\
\text { body flexibility } \\
\text { and agility - jump- } \\
\text { ing up and down }\end{array}$ & $\begin{array}{l}\text { Any traditional } \\
\text { ceremony as } \\
\text { entertainment. }\end{array}$ & Pride of Swazi culture \\
\hline
\end{tabular}

In 2013, the World Health Assembly agreed on a set of global voluntary targets which include a $10 \%$ decrease in insufficient physical activity by 2025 [10]. The 2030 Agenda for Sustainable Development and the commitment made by Eswatini's majesties (King Mswati III and Queen mother) provides an opportunity for EmaSwati to refocus and renew efforts at promoting physical activity through leveraging the contributions of all relevant sectors, in particular, health, education, sports and technology to accelerate progress in achieving the targets set by Eswatini by 2022. Some of the policies set include; 'Shukuma' Eswatini (physical and emotional wellness program communities) aimed at community sport and recreation activities targeted to geriatrics and people with special needs. Inclusion of international partners in fighting against HIV/AIDS; and development of Curriculum Based Education (CBE) with a child-centered approach, and establishment of national ICT institutions which partners with tertiary institutions in running ICT programs across the country. Eswatini mandates all primary schools to do Health and Physical Education (HPE) [11] so that all children are exposed to Physical Activity and exercise from infant age. In recognition of the above, it is imperative to know the trends of physical activity among EmaSwati's different age groups so as to track progress Eswatini are making towards global physical activity targets.

Dance is primarily an integrated art form between technical and expressive aspects. Dance, being a special expression of human beings' motor behaviors [12] is the art of reflecting inner world to outside, self-explanation and self-expression through movements [13]. Dance, containing sports, exercise science, and art in itself- is the expression of a feeling presented with a moving body through a physiological process [14]. In addition, most dance performance requires high physiological capacity due to their characteristics which includes; a moderate-high intensity, high skill, and pre-dominantly intermittent activity [15], these can often be comparable among many elite performers. Individual dancers have the opportunity to do more exercise [16] to support their emotions, mental, spiritual, social and physical being [1720], understanding the correlation between body and mind; the psycho-therapeutic dimension of movements should be used [21, 22].

Literature reveals the importance of engaging in regular physical exercise for the prevention of several chronic diseases as well as for improving psychological well-being and overall quality of life [23-28]. For these reasons understanding the physiology and importance of fitness is equally important as learning a dance skill $[29,30]$. As such, the significance of physical fitness in dance is a disputed topic within both dance teaching and training settings and in dance medicine and science literature [15]. Dance has such physical restrictions as muscle mass, joint structure, size, weight, flexibility, balance and place [31,32]. Therefore, dance should be addressed with focus on the presence of an underlying science foundation as an important pre-requisite to successful and sustained dance performance. By being amongst 
the most aesthetic and rhythmic way of movement, dance becomes technical and complex activity that contains exercises that strengthen the skeleton-muscle system as well as improves coordination by enabling the body to move freely in space/time [4]. While dance has several similar characteristics with sport there are an also intrinsic difference which bring a new dimension to body awareness, improves imagination and dynamic harmony $[26,33]$. The central nervous system (CNS) that provides balance determines the place, position and direction of the body in space and decides whether or not body should be moving or standing firm $[34,35]$. This is the reason why the general results obtained by other non-specific research cannot be applied to dancers [11].

To date, positive physiological and psychological effects of dancing upon the human body and its contributions to motor growth have been investigated through scientific methods [4]. Unlike sporting activities, dance offers freedom of movement to those who move away from physical activities and perform passive activities due to the effects of advanced technology. Dance science has been growing and is a new phenomenon in the southern Africa particularly Eswatini. This subject needs to be taught in schools, communities and to dancers on how to improve their performance through ensuring appropriate preparation during training. Therefore, the current paper discusses the physiological aspects such as physical fitness, energy systems, energy intake and expenditure, conditioning training and injury prevention, and rest in Eswatini traditional dances.

\section{Energy System in Dance}

Energy is about how the movement happens and is required for all physical work. Choices about energy include variations in movement flow and the use of force, tension, and weight [12]. Energy source varies during various activities. All dances use the element of energy, though in some instances it may be slow, supple, indirect energy - not the punchy, high speed energy of a fast tempo dance. Energy choices may also reveal emotional states. With dance, depending on different forms the energy source also varies. There are several ways in which the body converts chemical energy into mechanical energy to fuel the muscles during exercise. Getting knowledge about energy systems and various training protocols to improve energy sources can assist to improve dance performance. The field of exercise physiology encompasses knowledge about 2 different energy systems (anaerobic and aerobic systems) and how they come into play during physical activity and exercise [36-39]. Anaerobic system follow 2 steps which are; ATP-PC (ATP = Adenosine Triphosphate, a high-energy molecule made up of Carbon, Hydrogen, Oxygen and Nitrogen. PC $=$ Phosphocreatine another high-energy molecule found in the sarcoplasm of muscle fibers) and the Lactic Acid system. The first uses phosphocreatine (PC), only available in small amounts, can act upon sudden increases in energy demand. Creatine phosphate is a high-energy molecule stored in muscle and joins with the resultant ADP to create ATP and Pi [39]. Carbohydrate is used in all types of physical activity but its use is primarily in moderate to intense exercise, while fat is the primary source of fuel for endurance exercise [40]. When energy is needed the body breaks down the Adenosine Triphosphate using an enzyme called ATPase into ADP (Adenosine Diphosphate). This in turn breaks down the Phosphate (P) and so provides energy. To resynthesise ATP the body will reverse the above process, it should be noted that it takes less energy to and resynthesise ATP than it does to break it down [39]. When one of these bonds breaks down, forming adenosine diphosphate (ADP) and a single phosphate (Pi), energy is released. Breaking down ATP increases the volume of ADP, which triggers the release of an enzyme known as Creatine Kinase, this will start the breakdown of PC into phosphate and Creatine; this being an exothermic reaction it gives the energy needed to resynthesise ATP at a fast rate. The mitochondrial, aerobic system of ATP production provides much of the energy required for lowto moderate-intensity exercise, for example during early dancing exercises within a traditional dance group. Once exercise intensity increases above a certain point, aerobic pathways cannot meet this demand, and ATP synthesis also begins to occur as a result of anaerobic pathway. This system provides very high energy, but lasts less than 10 seconds during maximal effort [41].

Lactic Acid System is also known as Anaerobic Glycolysis because the initial process is the same as Aerobic Glycolysis only without oxygen. After the 20 seconds of the ATP-PCr system, the body requires another ingredient- muscle glycogen (glucose) to be added to continue [39]. This system breaks down carbohydrate, a fuel in limited supply in the body, to produce medium amounts of power for medium amounts of time. Exactly the same 10 chemical reactions take place within the sarcoplasm (the high energy substance found within the muscle fibers) and turn the Carbohydrate into Pyruvic acid plus 2 molecules of ATP. This time the action being without oxygen the carrier molecule $\mathrm{NAD}+$ cannot off load the Hydrogen $(\mathrm{H}+)$ this being a by-product of Glycolysis and causes a buildup of $\mathrm{H}+$ in the cells in the absence oxygen converting carbohydrate $>$ sugar $>$ glucose $>$ glycogen $>$ ATP [39-41].

Focusing on these aspects can improve the efficiency and quality of dance performance. Guidetti et al. (2007) [42] reported that warm up activity is almost universally performed by athletes prior to their participation in training or competition. The passive warm up involves raising muscle or core temperature by some external means, whereas the active warm up involves exercise and is likely to induce greater metabolic and cardiovascular changes than passive warm up [43]. Classical dance takes place between sport and art involving rhythm's sense, aesthetic and technical ideals, and a good level of training.

The increase in acidity is broken down when the pyruvic acid accepts the $\mathrm{H}+$ and forms lactic acid. If oxygen were present the $\mathrm{H}+$ would be moved to the mitochondria for use in the Krebs cycle (the citric acid/tri-carboxylic acid cycle) part of the second phase 
of the aerobic metabolic cycle. Lactic acid interferes with muscle contraction and disrupts the joining of calcium to the troponin. The acid will also irritate free nerve endings within the muscle and cause pain to a dancer. Lactate is not a waste product but is actually an important part of anaerobic and aerobic metabolism. When the exercise was preceded by a warm up, there was a significant decrease in fractions attributable to anaerobic alactic source (the energy phosphate splitting during exercise) and to anaerobic contribution from blood lactate accumulation. Due to rising amounts of pyruvate within the cell, it is converted to lactate, and, as a consequence of this process, the $\mathrm{pH}$ within the muscle decreases, which may affect muscular contraction adversely [44]. The exercise intensity at which the levels of blood lactate increase above resting levels is known as the lactate threshold [45]. The aerobic source fraction increased significantly when the exercise was preceded by active warm up. It is imperative that EmaSwati dancers should carry warm up seriously since it may allow subsequent tasks to start with an elevated baseline $\mathrm{VO}_{2}$; consequently, it may occur a decreased oxygen deficit involving a lesser contribution of the anaerobic sources. With the understanding that whether the energy system dominant is anaerobic or aerobic, aids in planning specific training programs in dancers.

The Oxidative/Aerobic system is noted when the dancer's body is able to take in, transport and use oxygen. It requires low to moderate intensity exercise, powered by aerobic metabolic function fuelled by the body's stores of carbohydrates and fats. This system has 3 stages: Glycolysis (the breaking down of Carbohydrate into Pyruvic acid, which produces 2 ATP molecules), Kreb cycle (the Citric Acid Cycle or the Tri-carboxylic Acid Cycle which is responsible for the second phase of aerobic metabolism), and the Electron Transport Chain (occur in the mitochondria through splitting into proton $\mathrm{H}+$ and electron $\mathrm{H}$ - and resynthesise of ATP). Carbohydrate is stored in the muscles and the liver and can sustain approximately 60 - 80 minutes exercise. As the carbohydrate is used up, the body then has to rely on the stores of fat, this being so, the energy output will drop because fat does not produce the same level of energy as carbohydrate. This threshold can be increased as a result of endurance training, and therefore allows an individual to work at a higher intensity without the accumulation of lactate [46], or before becoming fatigued [45]. During aerobic exercise, the muscles of a body with a good store of carbohydrate and plenty of oxygen can contract repeatedly without fatigue. Maximal Aerobic power expressed as $\mathrm{VO}_{2}$ max as well as the muscle power is different in sports.

It should be noted that Eswatini traditional dances, for example, Ummiso which take more than 3 hours during the Marula Festival and the Umhlanga (Reed Dance); higher levels of aerobic fitness, as a result of endurance-type training [45, 47] may aid intermittent-type dancer by increasing the lactate threshold, by increasing the ability of the aerobic system to provide energy for longer [48]. Better aerobic fitness will also enhance the dancer's recovery from anaerobic exercise by aiding the restoration of muscle to its pre-exercise state, by improving lactate and potassium removal and enhancing $\mathrm{PCr}$ regeneration [49]. It is therefore logical to suggest that EmaSwati dancers who perform predominantly intermittent types of exercise ought to have a good level of aerobic fitness.

Importantly, the dancer's energy choices may reveal their emotional states. For example, the Swazi 'Sibhaca' and 'Ingadla' dances which are mainly for entertainment have a powerful push which might be aggressive or playfully boisterous depending on the environment, intent and situation. Other forms of energy can be easily expressed in words, others spring from the movement itself and are difficult to label with language. In some cases, differences in the use of energy are easy to perceive; other times these differences can be quite subtle and confusing. Perhaps more so than the other elements, energy taps into the non-verbal yet deeply communicative realm of dance.

\section{Physical Fitness in Dance}

Having noted how the Eswatini calendar is packed throughout the year with traditional and cultural activities which are more exclusively carried through physical exercise, it is important to evaluate physical fitness during resting and performance in each individual. Physical fitness can be defined as individuals' ability to meet the demands of a specific physical task efficiently and effectively without fatigue [50-52]. Like the generality of sports, dance fitness depends on the individuals' ability to work under various training protocols including anaerobic and aerobic conditions, resistance training and on their capacity to develop high levels of muscle tension, thus, muscle strength [52], joint and muscle mobility/flexibility and body composition [53] are essential in dancer fitness improvement. However, no single fitness measurement can predict success in dance, as they vary markedly depending on numerous parameters including age, gender and level of performance [50]. Through dancing, dancers can develop a fit and aesthetic posture and attain balance, personal discipline, self-control, concentration, flexibility, endurance, speed and strength [54]. The essential physical qualifications for the dance are strength, flexibility, special endurance, balance, and body coordination [55]. In that regard, dancing can be seen as a medium for increasing leisure-time physical and social activity. Components of physical fitness; strength, endurance, flexibility, agility and co-ordination have been discussed below.

\section{Muscular Strength}

The Swazi traditional dancers are not trained following the specified training periodized program, which also specifies the physical fitness aspects. Though muscle strength is important in their dance activity at different levels, muscular strength is not generally being considered as a necessary ingredient for success $[56,57]$ in their traditional and cultural dances. This however, 
does not entail that improving force in the muscle groups they use in dancing may not be a resultant of enhancements in dance performance. Nevertheless, Gupta et al. 2004 [58] research found that dancers have greater hip external rotation strength (anglespecific torque) compared to non-dancers at university level. Literature also indicates that groups of university dancers lacked in strength of the hamstring muscle group, abdominals, the upper torso, arms and the front of the lower leg [59]. Despite gender and age differences among the Swazi dancers, it is important that there are encouraged to work on resistance training for hamstrings and quadriceps to improve in leg strength and dance performance with emphasis of not interfering with key artistic and physical performance requirements.

\section{Flexibility, Agility \& Co-ordination}

The short duration of Eswatini dances such as Ingadla, Sizingili, Kukhosha and various forms of Sibhaca are high kicking dances which encourage flexibility, agility and co-ordination training. It has to be appreciated these dances resemble EmaSwati's passion in keeping their cultural identity and skills. Though there is no literature as yet on the dancers testing and measurement results concluded. Flexibility, which is the range of motion available in a joint, is an important characteristic of physical and health related fitness. The dances have greater than normal flexibility in most lower extremity joints which is almost similar to the conclusions made by Aiyegbusi et al. (2018) [60] for ballet, hip hop and African traditional dancers. On a more specific base, 'Sibhaca' and 'Ingadla' dances encourage more flexibility and co-ordination through a passive hip external rotation, flexion, abduction and knee extension following a less range of motion (ROM) in passive hip adduction and internal rotation, followed by high demand on agility though this can be subjective [57]. Furthermore, this pattern is more pronounced in old and experienced male and female dancers, suggesting that it may be a direct result of dancing itself. Despite that there is a wide range of motion witnessed during various Swazi dances performances, dancers are required to have greater than normal hyperextension of the spine, flexible hamstrings and abductors [60] due to the demands of dance techniques and all year round calendar of traditional and cultural physical activities in Eswatini. Therefore, flexibility and stretching should be recognised and incorporated by EmaSwati dancers in their training program as they are a keystone of injury prevention, muscle recovery, and increased mobility for exercise enthusiasts [61].

\section{Injury Prevention, Nutrition \& Rest in Dance}

The information about various energy systems, analysing movements and muscle work, providing appropriate training, proper diet and psychological support play important role in the prevention of dance injuries. Despite that there is no record and data about injuries sustained during the different traditional and cultural events in Eswatini; dancers need to be fully acquainted with knowledge on injury prevention and management. It is imperative that dancing in Eswatini is not a funded field and hence injury related costs may not be discovered, if discovered they may not be covered.

Although injuries are inevitable in physical activity and sport, it is essential to recognize that appropriate nutritional strategies have the ability to reduce the risk of injuries as well as enhance the recovery if an injury should occur $[55,62]$. Notably, a good number of Eswatini traditional ceremonies, main activities which incorporate dances are done after taking lunch. Philips and van Loon (2011) [63] indicated that all athletic performers should engage with a properly qualified nutritionist who will promote a "food first approach" to prevent and treat injuries. Despite that there are no working nutritionists during Eswatini's traditional and cultural ceremonies, performing dances after lunch is done to allow dancers and the general population to have adequate energy intake before physical exercise. All traditional and cultural ceremonies are embraced by packages of meat (beef) and other food stuffs given to a particular group of people who were at the centre stage of the ceremony on the last day before they depart to their respective homes - for example, Umhlanga (Reed dance), the maidens (Timbali) receive the packages. EmaSwati refer the meat and food stuffs as 'Inkosi iphekile' laterally meaning that during Eswatini national ceremonies, 'Their Majesties' embrace and thank their people by giving them a meal mainly with meat. In line with this phenomenon, given the crucial role of dietary protein in muscle protein turnover, it is not surprising that much attention has been given to dietary protein in the prevention of muscle injuries [62]. The provision of dietary protein enhances the adaptive processes to both resistance-and endurancebased exercise [60], and therefore, attractive to hypothesize that increasing dietary protein may alleviate markers of muscle damage [62].

Due to few professional and competitive dance groups in Eswatini the number of dancers in a group, though not explicitly noted, some or a dance may force the dancer to perform with minor injuries which may negatively result in more severe injuries [57]. Interestingly, the Swazi tradition and culture give responsibility of monitoring of injuries to the trainers who may be relatives, elders at various levels and only during the national events injuries are under Ministry of Health through its various departments, exemplary, the Emergency Medical Services (ambulances and mobile clinics). However, there is a great need for an intervention any level to help prevent injuries among their dancers [57]. Notably, dancers do get injured and the effects of these injuries may be highly detrimental. Like in any sport, many factors that contribute to injury in dancers can be modified and minimised. Although there is an assumption that dancers' movements are not capable of generating sufficient power to cause the muscular injuries as witnessed in sports, such injuries can be seen. Literature shows that aerobic dance appears to offer the potential for fitness enhancement with a minimal risk of injury [64]. 
These injuries can be circumvented by appropriate warmup procedures, information and methodology from the body therapies, basic conditioning principles, development of suitable levels of flexibility and strength, supplemental training and corrective work for alignment problems $[51,65]$. Unsafe surfaces are also implicated, and dancing on even, sprung floors may decrease injury incidence [57]. The lower back seems to be the most frequently injured site, which together with pelvis, legs, knees and feet, accounts for more than $90 \%$ of injuries [66]. Muscular strength and strength exercise which includes versatile movements and high peak forces, are more effective in bone formation and are a means of preventing osteoporosis in dancers $[57,65]$.

Despite that Swazi dances are done through passion and respect for EmaSwati tradition and culture, Fuhrmann et al. (2010) $[66,67]$, suggests that educating dancers about injury prevention is important, effective and comprehensive cost cutting intervention program. Injury prevention topics should include; body composition, nutrition, weight management, rehabilitation [12] and psychology among others. The nature of activity and the aesthetic component of dance, it is known that dancers are striking with apparent musculature, having a low body fat percentage and low measurements of waist, hips and thighs circumference [68, 69] which are critical to the aesthetic component of dance. It can be evidenced that the low body fat percentage in dancers may be a result of many years of active training. Dancers' body weight is constantly carried in space, thus moving dancer's own weight in performing different types of jumps, spins and other dance elements. Comparably, dancers and sport athletes are pressured with issues of nutrition and weight management [53], dancers are pressured to restrict dietary intake to meet the aesthetic requirements of dance [57]. Due to these restrictions which may force dancers to reduce body mass by lowering daily energy food intake, there are often malfunctions such as anorexia, amenorrhea, and even osteoporosis. Literature reveals that poor nutrition increases musculoskeletal injuries, psychological imbalance and leads to more severe medical problems $[53,57,70]$. International Association for Dance Medicine and Science emphasised that body composition plays an important role in dancers' health [71]. Appropriate quantification of key structural mechanisms of the body; muscle, bone and fat are important aspects of anthropometric profiles that can contribute to optimizing physical performance [53]. Despite that optimal body composition varies from activity to activity [71], dancers need a certain percentage of fat to enable them to perform according to the activity demands. Body composition using anthropometric measurements are essential in determining the dancer's potential [72] in jumping higher, turning faster, and duration of physical training survival, rehearsing, and performing and after performing recovery [73].

For dancers to achieve appropriate body composition for optimal performance there is need of a balance of appropriate energy intake (nutrition) and energy expenditure (physical activity) [72]. Energy intake and energy expenditure of dancers should be explored as done in a number of sports; for example, football, athletics, taekwondo, and gymnastics among others. Brown et al (2017) [73] denotes that female contemporary dancers are at risk of energy deficiency, particularly during periods of scheduled dance training. With this in mind, the EmaSwati maidens (Timbali) and women (Lutsango) who attend the Reed dance (Umhlanga) and the Marula (Maganu) Festival may not be spared to such risks and susceptible to the numerous health and performance impairments associated with energy imbalance. Appropriate macronutrient intakes are crucial for maintaining the demands of training, performance and recovery [61]. Importantly, the knowledge regarding appropriate nutrition for sport and exercise performance should be taught from early years of development as this will help dancers to understand the variability of nutritional intakes and energy expenditures between in-season and off-season. It should be noted that unbalanced and irregular nourishment is connected with injuries of loco motor system.

The Eswatini calendar of traditional and cultural activities encourages rest and recovery of different dance age groups. It is needless to emphasize the importance of rest in dance training for optimal performance. Planned proper recovery and rest from physical training helps decrease fatigue reduce the incidence of injury and accelerate muscle regeneration between training sessions [74, 75]. Whilst the principle of overloading is welldocumented, over-training negatively impacts the dancer's health and performance. An imbalance between training and recovery may cause severe and prolonged fatigue, negative behavior changes and loss of motivation [71]. To achieve optimal performance, it is recommended that dance educators should prevent over-training by monitoring dance quality visa viz quantity, diet, hydration, rest, and sleep patterns [73].

\section{Conclusion}

Traditional and cultural dances offer unique freedom of movement. Dance development can be multi-dimensional among individuals bringing about positive improvements when individuals dance as a sportive activity, physical or cultural fulfillment. EmaSwati's tradition and culture stalwarts on the importance and significance of the song and dance among other things. Teaching dance science with focus of how dancers can improve their trained state and achieve optimal performance through understanding the cycles of periodization training and nutrition to allow them to prepare for events more efficiently is of paramount importance. Dancing optimal performance and effective injury prevention could be reached after making critical observation, assessment and research of specific dance characteristics such as nutrition, physical conditioning and scientific training methods. Therefore the southern African countries should consider the following recommendations;

a. document traditional and cultural dances 
b. include dance in the primary and secondary education curriculum

c. introduce curriculum in dance science in the tertiary education

d. educate and train the trainers for community dancers

e. research on genre specific, with detailed accounts of technical and stylistic elements of movement.

\section{Acknowledgement}

No sources of funding were used to assist in the preparation of this manuscript and the authors have no conflicts of interest that are directly relevant to its content. The author give special thanks to Eswatini National Museums' Ms Nomsa Dlamini, Education Officer for her essential help and advice in the history of the Swazi traditional and cultural dances.

\section{References}

1. B\&T Swaziland Limite (2018).50th Double Golden Jubilee Celebrations: Celebrating Peace, Stability and Development. (Proceedings), Eswatini.

2. Forsyth-Thompson C (2019) Eswatini Discovery. Eswatini's Official Tourist Guide. Eswatini, Mbabane.

3. Sustainable Development Goals Knowledge Platform (website) Accessed on 02 March 2020.

4. Bastug G (2018) Examination of Body Composition, Flexibility, Balance, and Concentration Related to Dance Exercise. Asian Journal of Education and Training 4(3): 210-215.

5. Dlamini SB (2008) Women and Theatre for Development in Swaziland. The School of Oriental and African Studies The University of London PhD Thesis. Published by ProQuest LLC.

6. Matsebula JSM (1988) A history of Swaziland. Cape Town: Longman $1-16$.

7. Kuper H (2008) "Incwala in Swaziland: Of growth and kingship" The University of Swaziland: Swaziana: Swaziland's own special collection archives. Swaziland.

8. Kuper H (1978) Sobhuza II: Ngwenyama and King of Swaziland: The story of a hereditary rider and his country. London: Duckworth.

9. Guthold R, Stevens GA, Riley LM, Bull FC (2018) Worldwide trends in insufficient physical activity from 2001 to 2016: a pooled analysis of 358 population-based surveys with 1.9 million participants. Lancet Global Health 6: e1077-1086.

10. World Health Organisation (2018). Physical Activity. Accessed on 12 March 2020

11. Ministry of Education and Training (2018) Eswatini National Curriculum Framework for General Education. National Curriculum Centre, Manzini, Kingdom of Eswatini.

12. Dube A, Gouws C, Gundani MP (2019) Physical Activity Practice Pattern among Undergraduate Students in the Faculty of Health Sciences. Int J Sports Sci Med 3(3): 084-090.

13. Hugel FM, Cadopi, Perrin P (1999) Postural control of ballet dancers: A specific use of visual input for artistic purposes. International Journal Sports Medicine 20(2): 86-92.

14. Cantekin D (2011) Examination of movement related terms used in dance. Master thesis.

15. Esen A (2012) The effect of dance training on joint position sensing levels. Master Thesis. İzmir (Turkey): Ege University, Health Sciences Institute.

16. Beck S, Redding E, Wyon MA (2015) Methodological considerations for documenting the energy demand of dance activity: a review. Frontiers in psychology 6: 568.

17. Lin CM (2005) Perception of dance instructors regarding general dance education curricula in Taiwan. USA: The University of South Dakota.

18. Schmid A, Peper E (1998) Strategies for training concentration, In J.M. Williams (Ed.), Applied sport psychology: Personal growth to peak performance ( $3^{\text {rd }}$ Edn). Mountain View, CA: Mayfield. 316-328.

19. Moran A (2004) Sport and Exercise Psychology: A critical introduction. Routledge.

20. Murciaa CQ Kreutzb G Cliftc S, Bongarda SN (2010) Shall we dance? An exploration of the perceived benefits of dancing on well-being. Arts and Health 2(2): 149-163.

21. Kierr S (2011) Is dance/movement therapy relevant to the process of achieving a healthy sexuality? American Journal of Dance Therapy 33 (1): 42-56.

22. Payne H, Stott D (2010) Change in the moving body mind: Quantitative results from a pilot study on the use of the Body mind approach (BMA) to psychotherapeutic group work with patients with medically unexplained symptoms (MUSS). Counseling and Psychotherapy Research 10(4): 295-306.

23. Strassel JK, Cherkin DC, Steuten L, Sherman KJ, Vrijhoef HJM (2011) A systematic review of the evidence for the effectiveness of dance therapy. Alternative Therapies 17(3): 50-59.

24. Warburton DE, Nicol CW, Bredin S (2006) Health benefits of physical activity: The evidence. Canadian Medical Association Journal 174(6): 801- 809.

25. Haskell WL, Lee IM, Pate RR, Powell KE, Blair SN, et al. (2007) Physical activity and public health: updated recommendation for adults from the American College of Sports Medicine and the American Heart Association. Medicine and Science in Sports and Exercise. ; 39(8):142334.

26. Baldari C, Guidetti L (2001) $\mathrm{VO}_{2} \max$; ventilatory and anaerobic thresholds in rhythmic gymnasts and young female dancers. J Sport Med Phys Fitness 41(2): 177-182.

27. Rehfeld K, Lu Èders A, Ho Èkelmann A, Lessmann V, Kaufmann J, Brigadski T, et al. (2018) Dance training is superior to repetitive physical exercise in inducing brain plasticity in the elderly. 13(7): e0196636.

28. Zaletel P, Gabrilo G, Peric M (2013) The Training Effects of Dance Aerobics, Collegium Antropologicum 37(2): 125-130.

29. Gao Z, Zhang T, Stodden D (2013) Children's physical activity levels and psychological correlates in interactive dance versus aerobic dance Journal of Sport and Health Science 2(3): 146-151.

30. Angioi M, Metsios G, Koutedakis Y, Wyon MA (2009) Fitness in contemporary dance: a systematic review. International journal of sports medicine 30 (7): 475- 484.

31. Hui E, Chui BT, Woo J (2009) Effects of dance on physical and psychological well-being in older persons. Archives of Gerontology and Geriatrics 49(1): e45-50.

32. Dündar U (2012) Training theory. Ankara, Turkey: Nobel Publication Distribution.

33. Zorba E, Saygin Ö (2013) Physical activity and physical fitness. $3^{\text {rd }}$ Edn. Frat printing 138-151.

34. Temel SD, Temel T (2016) The contribution of dance education 
to physical-mental development, movement ability and learning processes. Fine Arts (NWSAFA) 11(4): 171-180.

35. Deliagina TG, Zelenin PV, Beloozerova IN, Orlovsky GN (2007) Nervous mechanisms controlling body posture. Physiology \& Behavior 92 (1-2): 148-154.

36. Horak FB, Macpherson JM (2011) Postural orientation and balance. Comprehensive Physiology: 255-292.

37. Krasnow D, Chatfield SJ (1996) Dance Science and the Dance Technique Class. Impulse 4: 162-172.

38. Mehta P, Choi SM (2017) The Role of Exercise Physiology in Dance. Research in Dance and Physical Education 1(1): 29-35.

39. Marieb E N (2001) Anatomy \& Physiology. $1^{\text {st }}$ Edn. Benjamin Cummings.

40. Greenhaff P, Hultman E, Harris R (2004) Carbohydrate metabolism. In Poortmans J (ed.) Principles of exercise biochemistry. Basel: Karger 46: 108-151.

41. Åstrand P, Rodahl K, Dahl H, Stromme S (2003) Textbook of Work Physiology: Physiological Bases of Exercise. Human Kinetics

42. Guidetti L, Emerenziani GP, Gallotta MC, Baldari C (2007) Effect of warm up on energy cost and energy sources of a ballet dance exercise. European Journal of Applied Physiology 99(3): 275-281.

43. Bishop D (2003) Warm Up I: Potential mechanisms and the effects of passive warm up on exercise performance. Sports Medicine 33(6): 439-454.

44. Sahlin K (1992) Metabolic Factors in Fatigue. Sports Medicine 13(2): $99-107$.

45. Jones AM, Carter H (2000) The effect of endurance training on parameters of aerobic fitness. Sports Med 29 (6): 373-386.

46. Wells CL, Pate RR (1988) Training for performance of prolonged economy following intensified training correlates with reduced exercise. In: Lamb DR, Murray R. Perspectives in exercise science and sports medicine 1(1): 357-391.

47. Ekblom B, Astrand PO, Saltin B, Stenberg J, Wallstrom B (1968) Effect of training on circulatory response to exercise. J Appl Physiol 24 (4): 518-528.

48. Twitchett EA (2009) Physiological demands of performance in Classical Ballet and their relationships with injury and aesthetic components. University of Wolverhampton. PhD Thesis.

49. Tomlin DL, Wenger HA (2001) The Relationship between Aerobic Fitness and Recovery from High Intensity Intermittent Exercise. Sports Medicine 31(1): 1-11.

50. Koutedakis Y, Jamurtas A (2004) The Dancer as a Performing Athlete Physiological Considerations. Sports Med; 34 (10): 651-661.

51. Corbin C , Masurier GL (2014) Fitness for Life. $6^{\text {th }}$ Edn. Human Kinetics.

52. Lunga CM (2019) Essential Skills for Highly successful Youths. Nurturing competitive leaders of the $21^{\text {st }}$ century and beyond. Novus Print, Cape Town, South Africa.

53. Dube A, Gundani PM (2018) Anthropometric and somatotype characteristics of undergraduate students of the National university of Science and Technology, Zimbabwe. Advances in Obesity, Weight Management and Control 8(3): 188-192.

54. Gökce E (2006) The effect of 20-week special stretching exercise program on flexibility and dance performance in dancers who are trained in professional dance. Master Thesis, Istanbul (Turkey): Mimar Sinan University, Social Sciences Institute.

55. Hugel FM, Cadopi, Perrin P (1999) Postural control of ballet dancers: A specific use of visual input for artistic purposes. International Journal
Sports Medicine 20(2): 86-92.

56. Koutedakis Y, Sharp NCC (1999) The Fit and Healthy Dancer. Chichester: Wiley

57. Mehta P, Choi S (2017) The Role of Exercise Physiology in Dance. Research in Dance and Physical Education 1(1): 29-35.

58. Gupta A, Fernihough B, Bailey G, Bombeck P, Clarke A, et al. (2004) An evaluation of differences in hip external rotation strength and range of motion between female dancers and non-dancers. Br J Sports Med 38 (6): 778-783.

59. Plastino JG (1990) Incorporating dance science into technique class and performance training. Journal of Physical Education, Recreation, and Dance 61(9): 26-27.

60. Ibifubara AA, Odebiyi OD, Udegbeh SO (2018) Lower Limb Flexibility and Risk of Injury in Professional Dancers: A comparative study of Ballet, Hip-Hop and African traditional dances. Accelerando Belgrade Journal of Music and Dance 3: 10.

61. Knudson DV (2013) Warm-up and flexibility. In book: Conditioning for Strength and Human Performance. $2^{\text {nd }}$ Edn, Chapter 9: Warm-up and flexibility.

62. Close G, Sale C, Barr K, Bermon SF (2019) Nutrition for the Prevention and Treatment of Injuries in Track and Field Athletes. International journal of sport nutrition and exercise metabolism. 29(2): 1-26.

63. Phillips SM, Loon LJ (2011) Dietary protein for athletes: from requirements to optimum adaptation. Journal of sports sciences 29(1): S29-38.

64. Garrick JG, Gillien DM, Whiteside P (1986) The epidemiology of aerobic dance injuries. Am J Sports Med 14(1): 67-72.

65. Watson T, Graning J, McPherson S, Carter E, Edwards J, et al. (2017) Dance balance and core muscle performance measures are improved following a 9-seek core stabilization training program among competitive collegiate dancers. International Journal of Sports Physical Therapy 12(1): 25.

66. Koutedakis Y, Pacy PJ, Carson RJ (1997) Health and fitness in professional dancers. Med Probl Perferm Art. 12 (1): 23-27.

67. Fuhrmann TL, Brayer A, Andrus N, McIntosh S (2010) Injury prevention for modern dancers: a pilot study of an educational intervention. Journal of community health 35(5): 527-533.

68. Beck S, Redding E, Wyon MA (2015) Methodological considerations for documenting the energy demand of dance activity: a review. Frontiers in psychology 6(6): 568.

69. Stošić D, Uzunović S, Veličković S, Mladen Živković M, Vladan Petrović V, et al. (2015) Effects of Dance Aerobic on Body Composition. International Scientific Conference, FIS Communications.

70. Dube A, Gundani MPD, Lunga CM, Rastogi S (2018) Evaluation of Nutritional Status of EmaSwati Adolescent Swimmers. Journal of Advances in Sports and Physical 1(1): 24-30.

71. International Association for Dance Medicine and Science. Dance Fitness. Accessed on 22 February 2020.

72. Wilmerding MV, McKinnon MM, Mermier C (2005) Body composition in dancers: A review. Journal of Dance Medicine \& Science 9(1): 18-23.

73. Brown MA, Howatson G, Quin E, Redding E, Stevenson EJ (2017) Energy intake and energy expenditure of pre-professional female contemporary dancers 12(2): e0171998.

74. Angioi M, Metsios G, Twitchett EA, Koutedakis Y, Wyon, M (2012) Effects of supplemental training on fitness and aesthetic competence parameters in contemporary dance: a randomised controlled trial. Medical problems of performing artists 27(1): 3-8. 
This work is licensed under Creative

Commons Attribution 4.0 Licens

DOI: 10.19080/JPFMTS.2020.08.555727
Your next submission with Juniper Publishers will reach you the below assets

- Quality Editorial service

- Swift Peer Review

- Reprints availability

- E-prints Service

- Manuscript Podcast for convenient understanding

- Global attainment for your research

- Manuscript accessibility in different formats

( Pdf, E-pub, Full Text, Audio)

- Unceasing customer service

Track the below URL for one-step submission https://juniperpublishers.com/online-submission.php 